\title{
Creation project effectiveness of the Air Force Sports Center in the perspective of stakeholders*
}

\author{
Eficacia del proyecto de creación del Centro Deportivo de la Fuerza Aérea desde \\ la perspectiva de las partes interesadas
}

Eficácia do projeto de criação do Centro de Desportos da Aeronáutica na perspectiva dos stakeholders

Cel Inf Pedro Celso Gagliardi Palermo, Master

Brazilian Air Force Sports Commission - CDA

Rio de Janeiro/RJ - Brazil pcgagliardi@gmail.com

\begin{abstract}
This study aimed at analyzing how the critical success factors in the optics of its stakeholders, impact the effectiveness of the deployment project of the Air Force Sports Centre (CDAer). The main actors involved in the process were identified and subjected to an investigation through a questionnaire. The instrument was based on the critical success factors proposed by Pinto and Slevin (1987). The questions were adapted to the reality of the proposal in order to allow analysis of the degree of importance of each critical and strategic effectiveness and project tactics. The results showed that most of the stakeholders understand that the project follows the right track and has a high strategic rather than tactical effectiveness, but some need to receive more attention so that their expectations are met. The methodology enabled even to point out potential errors that may occur in the implementation of the CDAer and that they should be better managed. In conclusion, we suggest that a clear diagnosis of their problems is to be carried out, especially those related to customers, personnel, financial resources and the organizational structure, respecting the balance between the strategic and tactical effectiveness of the proposal in order to cater to all interested parties.
\end{abstract}

Keywords: Stakeholder assessments. Military sport. Sports management. Strategic and tactical effectiveness.

Received / Recibido / Recebido $09 / 10 / 14$
Accepted / Aceptado / Aceito

07/22/15

\footnotetext{
*This study was the subject of the author's Final Paper, supervised by Prof. Ricardo de Moura, referring to the Advanced Course in Sports Management (CAGE), years 2013-2014, offered by the Brazilian Olympic Institute (IOB), linked to the Brazilian Olympic Committee (COB) and the Olympic Solidarity.
} 


\section{RESUMEN}

El estudio tuvo por objeto analizar la forma en que los factores críticos de éxito, desde el punto de vista de las partes interesadas, ejercen impacto sobre la eficacia del proyecto de implantación del Centro de Deportes de la Fuerza Aérea (CDAer). Se identificó a los principales actores involucrados en el proceso y se los sometió a una investigación por medio de un cuestionario. El instrumento se basó en los factores críticos de éxito propuestos por Pinto y Slevin (1987). Las preguntas se adaptaron a la realidad de la propuesta con el fin de permitir el análisis del grado de importancia de cada factor crítico, así como la eficacia estratégica y táctica del proyecto. Los resultados mostraron que la mayoría de las partes interesadas consideran que el proyecto está en el buen camino y tiene una eficacia más estratégica que táctica, sin embargo, algunos necesitan recibir más atención para que se satisfagan sus expectativas. La metodología aplicada también permitió señalar posibles errores que pueden ocurrir en el desarrollo de la implantación del CDAer, que deben ser mejor administrados. En conclusión, se sugiere la realización de un diagnóstico claro de sus problemas, especialmente de los relacionados con los clientes, el personal, los recursos financieros y la estructura orgánica, respetando el equilibrio entre la eficacia estratégica y táctica de la propuesta, con el fin de satisfacer a todos los interesados.

Palabras clave: Evaluación de las partes interesadas. Deporte militar. Gestión deportiva. Eficacia estratégica y táctica.

\section{RESUMO}

O presente estudo teve por objetivo analisar de que forma os fatores críticos de sucesso, na ótica dos seus stakeholders, impactam na eficácia do projeto de implantação do Centro de Desportos da Aeronáutica (CDAer). Os principais atores envolvidos no processo foram identificados e submetidos a uma investigação por meio de questionário. O instrumento teve por base os fatores críticos de sucesso propostos por Pinto e Slevin (1987). As perguntas foram adaptadas à realidade da proposta, de forma a permitir a análise do grau de importância de cada fator crítico, bem como a eficácia estratégica e tática do projeto. Os resultados demonstraram que a maior parte dos stakeholders entendem que o projeto segue um bom caminho e apresenta uma eficácia estratégica maior que tática, no entanto alguns necessitam receber maior atenção para que suas expectativas sejam atendidas. $A$ metodologia empregada possibilitou ainda apontar os erros potenciais que podem ocorrer no desenvolvimento da implantação do CDAer e que devem ser melhor gerenciados. Como conclusão, sugere-se que seja realizado um claro diagnóstico de seus problemas, principalmente dos relacionados aos clientes, ao pessoal, aos recursos financeiros e à estrutura organizacional, respeitando-se o balanceamento entre a eficácia estratégica e tática da proposta, a fim de atender a todos os interessados.

Palavras-chave: Avaliação de stakeholders. Esporte militar. Gestão esportiva. Eficácia estratégica e tática.

\section{INTRODUCTION}

With the advent of the Olympic Games in 2016, together with the completion of various sporting events of great magnitude, the Brazilian sport, including the military segment, has achieved a new level of development.

As a result of the V Military World Games of the International Council of Military Sports (CISM), held in Rio de Janeiro in 2011, military sports have been increasingly seen as an important developer of sports talents in the country, counting in its ranks on a major number of athletes worldwide, in various modalities.

The Air Force Command (COMAER), through the Air Force Sports Commission (CDA), has been studying the transformation of this unit into an Aeronautics Sports Center (CDAer). The project aims at meeting the domestic demand to the Aeronautics of physical and professional preparation of its military to carry out their professional activities, especially combating, as well as to contribute to the country's efforts in the development of high performance sports for the participation of Brazilian athletes at the Olympic Games.

Since its inception, the physical and organizational structure of the CDA has changed little and currently cannot satisfactorily meet all its demands. The lack of qualified personnel in research, the inadequate infrastructure and the difficulty to serve all of COMAER's Military Units prevent the Air Force military personnel and high-performance athletes to receive the proper technical-scientific and logistical-administrative support that assists in their performance.

In addition, budget constraints in investment funds in actions other than those directly related to the core business of the Air Force hamper the 
organization's progress in structural terms, which invariably compromises a broad performance of the CDA within COMAER.

With the coming of the Olympic moment experienced by the country, the Ministry of Sports is investing in the restructuring and modernization of CDA's sports facilities, with the construction of modern equipment that will be used by foreign teams during the period of preparation for the 2016 Olympic Games.

The proceeds from the Ministry of Sports for that, in addition to meeting the Olympic demands, will transform the campus of the CDA in a modern sports center. It is hoped that this legacy, which will be under the responsibility of COMAER after the event, could be administered in order to meet both the needs of the Air Force and the national sport.

The financial support of the Ministry of Sports solves the financial issue for the restructuring of the Organization's infrastructure, but it is crucial to understand how management processes will be carried forward to meet the demands of interested parties (stakeholders) of different natures.

To know the demands and to satisfy stakeholders is the key to an organization's survival (FREEMAN, 1984). This statement directly expresses the importance of those most interested in the success of a particular project. And, in the case of the CDAer's creation, it is no different.

The problem therefore arises from the following concerns: Is the CDAer being designed so as to comply with the demands expected from each stakeholder group?

The aim of this study was to examine how the critical success factors, in the view of stakeholders, impact on the effectiveness of CDAer's implementation project. As for the specific goals, those are:

1. To identify key stakeholders involved in CDAer's creation project;

2. To adjust the critical success factors to the specificities of CDAer's creation project, as proposed by Pinto and Slevin (2007);

3. To identify how stakeholders perceive the degree of importance of critical success factors (FCS), affects the process of creation of the CDAer; and

4. To analyze, according to the degree of importance attributed by the stakeholders to the FCS, the effectiveness of the project and its latent errors.
This study finds justification in deepening Motta's quote (2012), in which the author concludes that, from the end of the twentieth century, management theories have an ever more focused approach to the satisfaction of the desires of consumers, as these direct the efforts and resources of effective organizations.

\section{THEORETICAL FOUNDATIONS}

To Santos (2008), the stakeholder analysis contributes to the formulation of a logical structure that assists the project management to identify appropriate strategies and to monitor possible conflicts of interest.

According to Goldschmidt (2007), the needs and expectations of each group vary, so it is important for each of them to realize that their needs and expectations are being met.

In order to meet or exceed such expectations, Rabechini (2007) suggests the application of a stakeholder management system. In this sense, the author shows that managing interested parties requires determining needs and implementing actions aimed at meeting expectations, as described in Figure 1.

Figure 1 - Management model of stakeholders.

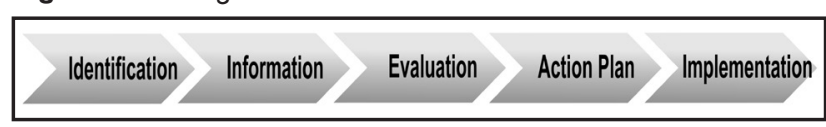

Reference: Rabechini (2007, p. 26).

In order to identify stakeholders, the author proposes a subdivision of stakeholders into primary and secondary. The primary ones are suppliers, sponsors, lenders, the local environment, project manager, functional manager, contractors and consumers. The secondary ones, in turn, are the social and political organizations, competitors, community, public, tourists, media, family members and environmentalists.

Santos (2008) orients that, when naming the interested parties, one cannot be too specific, nor is it essential to connect all existing actors with each other. Therefore, for practical reasons, it may be useful to consider groups and sub-groups within organizations, reducing the initial list to those whose common interests are more relevant.

Qualman (1997) teaches that some stakeholders hold greater power and can exert greater influence on the design, implementation and expected outcomes of a given project, categorizing them according to the matrix shown in Chart 1. 
Chart 1 - STAKEHOLDER Matrix.

\begin{tabular}{|c|c|}
\hline $\begin{array}{c}\text { C- Low Interest, High Power }(-/+) \\
\text { These stakeholders may influence the results of the } \\
\text { project, although their priorities are not the same of } \\
\text { the project's. For being a risk or obstacle, they should } \\
\text { be closely monitored. }\end{array}$ & $\begin{array}{c}\text { A- High Interest, High Power (+/+) } \\
\text { They are the most important actors. In this regard, } \\
\text { every effort should be made so that they are pleased } \\
\text { with the progress of the project. }\end{array}$ \\
\hline $\begin{array}{c}\text { D- Low Interest, Low Power (-/-) } \\
\text { This group must be monitored so that one may know } \\
\text { or power. Though seemingly of lesser importance, it } \\
\text { should not be overlooked. }\end{array}$ & $\begin{array}{c}\text { B- High Interest, Low Power (+/-) } \\
\text { This group is very helpful in providing ideas and } \\
\text { helping with small actions. It must be constantly kept } \\
\text { informed and will require special initiatives so that their } \\
\text { interests are protected. }\end{array}$ \\
\hline
\end{tabular}

Reference: Adapted from Qualman (1997).

Robinson et al. (2007), when specifically referring to the stakeholders of Olympic sports organizations (OEO), report that, normally, the financial aspects of the project determine the degree of interest and power (influence) of each group of stakeholders for the project, however, are not the only ones. They also reported that intrinsic cultural aspects interfere in the distribution of allocated resources, which helps explain certain decisions and why certain groups seem more important than others.

According to the study, the cultural aspect involves the use of power to direct, control and regulate the activities of an organization in what is known as Corporate Governance. These rules define the scope of action of the directors, how they are audited and what decisions should be made for the participation of all legitimately interested parties.

This aspect is particularly important for CDAer, since its project involves the creation of institutions inserted into different cultural backgrounds, resulting in many concerns that need to be contemporized from the project's birthplace.

For this, there must be a proper balance in decisionmaking, which should be backed by the goals set by the organization and aligned with the results expected by its stakeholders.

Santos (2008) reports that stakeholder analysis helps from the design stage to the development of the project's logical framework, helping to properly identify the participation of each of them. It also helps anticipate objections and allows them to propose appropriate actions to overcome them. The type of approach to relationship management with the actors will depend, among other aspects, on the situation, the degree of difficulty in obtaining information and the ease in achieving the actors involved. These, according to the author, are considered critical factors in choosing the stakeholder analysis approach.

Normally a project is conducted by a project manager that, ultimately, is a major contributor to the success.
However, Slevin and Pinto (1987) devote great importance to both managers and other interested parties, stressing that all groups should regularly assess the progress thereof and, more importantly, provide insight into various points of view, reinforcing the objectives and lending their views on the satisfaction of their expectations.

The authors propose 10 (ten) key factors that can be used for research and identification of potential risks that affect the success of any project, namely: Mission, Senior Management Support, Planning, Consulting Customer, Personnel, Technical Issues, Customer Acceptance, Monitoring, Communication and Reconciliation. The first three critical factors - Mission, Senior Management Support and Planning - refer to the project strategies, i.e., the process of establishing the overall goals and what is sought with them. The other factors are more related to the tactical aspects, action and achievement of established goals.

The authors also establish 4 (four) stages of a project during its life cycle: Conception, Planning, Execution and Termination. The level of effort of staff and stakeholders is growing from the Conception, through the planning and execution of the project. In this third phase, it reaches its apex to then decrease until the End stage. In the first two stages - Conception and Planning - strategy prevails; in the stages of Execution and Termination, tactics. In the end, both aspects - strategic and tactical ones - are practically on the same level of importance to the project success (SLEVIN; PINTO, 1987).

The authors conclude that: a) the use of the multifactor model is viable when seeking to understand the way that a given project is heading; b) these factors must be strategically designed from the beginning, since they are very sensitive for the success of the intended implementation; c) the project management and its stakeholders should develop strategic actions and tactics, noting the balancing and the transition of importance among the critical factors that define them; d) as the lifecycle progresses, one should think and act tactically. 
In addition to the financial and cultural factors mentioned, other variables of marketing nature also affect strategic planning and influence the management of an OEO.

According to Rocha and Bastos (2011), the management of an OEO is primarily engaged in the production and marketing of services related to sports. Production is concerned with the transformation of raw materials into the final product, while the sports marketing deals with all activities designed to meet the needs and desires of sport consumers through exchange processes (MULLIN; HARDY; SUTTON, 2007 apud ROCHA; BASTOS, 2011).

Motta (2012) says the product of a sports arena, as it will be the CDAer after completion of the infrastructure works, is characterized by tangible and intangible aspects, namely:

- Tangible: plant and equipment, furniture, functional team;

- Intangible: emotional appeals, cultural aspects institutional values.

In the case of CDAer, the investment of public funds in a military installation is seen as a guarantee that the resources are being employed in a credible organization. Toledo (2013) states that the Armed Forces are among the institutions that hold one of the highest rates of social trust. In this sense, although the resources for modernization of sports facilities (tangible product) are financed by the Ministry of Sports, the civic and institutional values, combined with the cultural aspects (intangible product) of Military Organizations, enclose the understanding that, somehow, either by winning medals, or for the best preparation of the military in national defense, there will invariably be a justifiable return to society.

According to Rabechini (2007), the success or failure of the implementation of a project depends on a correct understanding of the concepts and even the management requirements, especially when seeking to tailor partner desires to seemingly diffuse interests. In this case, one must identify and maximize potential synergies existing between them in order to favor the adoption of extensive planning able to generate concrete results to stakeholders.

That said, the application of a method of investigation and control of critical success factors gains importance, as one can anticipate, through its correct understanding, the identification of potential errors and propose appropriate recommendations and course corrections.

\section{METHODOLOGY}

For the identification of stakeholders, the method proposed by Rabechini (2007) and the group dynamics technique, known as brainstorming, were followed, among CDA officials who drafted the Proposal for the Creation of CDAer (BRAZIL, 2015). After determination of the primary and secondary actors, the determination of the 4 (four) major groups was followed, thus described:
G1 - General officers members of the High Command of the Air Force, the National Secretary for High-Performance Sports of the Ministry of Sports, the Chairman of CDA and the Chairman of the Military Sports Comission in Brazil (CDMB).

G2 - Senior officers of the Department of Aeronautics Education, the General Staff of the Air Force, the General Staff Command, the Internal Control Center of the Air Force, in addition to CDA project managers.

G3 - Presidents and Technical Directors of civilian and military Sports Organizations with which the CDA has a direct relationship, Advisors of the Secretary for High Performance Sports of the Ministry of Sports and members of the Brazilian Olympic Committee.

G4 - Career military personnel of the Air Force, civilian and military athletes and sections of Physical Education of the Military Schools.

In this study, the critical factors proposed by Slevin and Pinto (1987) were adapted and Santos' suggestion (2008) was adopted, that the stakeholder analysis will depend on the situation, the degree of difficulty in obtaining information and the ease in the stakeholders' reach.

To prepare the questionnaire, the contents of the document entitled Proposal for the Creation of CDAer (BRAZIL, 2015) was considered. Drawing on this paper, 45 (forty-five) questions were proposed, divided into 9 (nine) blocks of 5 (five) questions. The possible response options varied according to the Likert scale from 1 (one) to 7 (seven), where 1 (one) means 'I completely disagree' and 7 (seven) means 'I strongly agree'.

The questionnaire was validated through a pre-test, as directed by Marconi and Lakatos (2003, p. 203), through the evaluation of 4 (four) Senior Officers and 1 (one) Technical Director of the Sports Confederation, who suggested the necessary adjustments for the perfect understanding of it.

The questionnaire was sent to 66 (sixty-six) stakeholders, representatives of the 4 (four) groups identified. As an inclusion criterion in the study, it was decided to select those who had familiarity with the proposal to create the CDAer, albeit with varying degrees of depth. As the interests and the power of each stakeholder group is different, the questions addressed to each of them were selected, so that they had to answer only the ones by which they were affected the most.

Chart 2 presents the distribution of the issues by group of actors involved, as well as the amount of questionnaires distributed. 
Chart 2 - Distribution of questions by stakeholder group.

\begin{tabular}{|c|c|c|c|c|}
\hline $\begin{array}{c}\text { Questions Relating to } \\
\text { Critical Factors } \\
\end{array}$ & G1 & G2 & G3 & G4 \\
\hline FCE 1 - CDAer Central Goals & $\mathrm{x}$ & $\mathrm{x}$ & $\mathrm{x}$ & $\mathrm{x}$ \\
\hline $\begin{array}{c}\text { FCE } 2 \text { - COMAER Senior } \\
\text { Management } \\
\end{array}$ & $\mathrm{x}$ & $\mathrm{x}$ & & \\
\hline $\begin{array}{c}\text { FCT } 3 \text { - Organizational } \\
\text { Structure Proposed }\end{array}$ & $\mathrm{x}$ & $\mathrm{x}$ & $\mathrm{x}$ & $\mathrm{x}$ \\
\hline $\begin{array}{c}\text { FCT } 4 \text { - Personnel-Related } \\
\text { Questions } \\
\end{array}$ & $\mathrm{x}$ & $\mathrm{x}$ & & \\
\hline $\begin{array}{c}\text { FCT } 5 \text { - Financial Resources } \\
\text { for Vegetative Life }\end{array}$ & $\mathrm{x}$ & $\mathrm{x}$ & & \\
\hline FCE 6 - Planning & & $\mathrm{x}$ & & \\
\hline FCT 7 - Infrastructure & & $\mathrm{x}$ & $\mathrm{x}$ & $\mathrm{x}$ \\
\hline $\begin{array}{c}\text { FCT } 8 \text { - Client (potential } \\
\text { CDAer beneficiaries) }\end{array}$ & & $\mathrm{x}$ & $\mathrm{x}$ & $\mathrm{x}$ \\
\hline FCE 9 - Project Support & & $\mathrm{x}$ & $\mathrm{x}$ & $\mathrm{x}$ \\
\hline No. of questionnaires sent & 6 & 11 & 21 & 28 \\
\hline $\begin{array}{l}\text { No. and percentage of } \\
\text { questionnaires returned }\end{array}$ & $\begin{array}{c}1 \\
(16 \%)\end{array}$ & $\begin{array}{c}6 \\
(54 \%)\end{array}$ & $\begin{array}{c}13 \\
(61 \%)\end{array}$ & $\begin{array}{c}14 \\
(50 \%)\end{array}$ \\
\hline
\end{tabular}

Caption: FCE - Critical Strategic Factor; FCT - Critical Tactical Factor. Reference: The author.

Once returned the questionnaires, identification of modes and minimum values for each response and critical stakeholder group was held. The mode was used because it is a measure of central tendency representing the most frequent value. Minimum values in turn, represent the most negative views, which, once known, can add value in putting forward recommendations for possible project course corrections.

Then, the next step is to perform the summation of the modes and minimum values and correlate it to the percentage scores (Chart 3), from an adaptation of Pinto and Slevin's proposal (1998 apud RABECHINI, 2007).

Chart 3 - Scores percentage of critical success factors.

\begin{tabular}{|c|c|c|c|c|c|c|c|c|c|}
\hline Percentage & FCE & FCE & FCT & FCT & FCT & FCE & FCT & FCT & FCE \\
& $\mathbf{1}$ & $\mathbf{2}$ & $\mathbf{3}$ & $\mathbf{4}$ & $\mathbf{5}$ & $\mathbf{6}$ & $\mathbf{7}$ & $\mathbf{8}$ & $\mathbf{9}$ \\
\hline $100 \%$ & 35 & 35 & 35 & 35 & 35 & 35 & 35 & 35 & 35 \\
\hline $90 \%$ & 34 & 34 & 34 & 32 & 32 & 33 & 32 & 34 & 34 \\
\hline $80 \%$ & 33 & 32 & 32 & 30 & 30 & 31 & 30 & 33 & 32 \\
\hline $70 \%$ & 32 & 30 & 31 & 28 & 28 & 30 & 28 & 32 & 30 \\
\hline $60 \%$ & 31 & 28 & 30 & 27 & 27 & 28 & 27 & 31 & 28 \\
\hline $50 \%$ & 30 & 27 & 29 & 24 & 24 & 27 & 24 & 30 & 27 \\
\hline $40 \%$ & 29 & 25 & 27 & 22 & 22 & 26 & 22 & 29 & 25 \\
\hline $30 \%$ & 28 & 23 & 26 & 20 & 20 & 24 & 20 & 27 & 23 \\
\hline $20 \%$ & 26 & 20 & 24 & 18 & 18 & 21 & 18 & 25 & 20 \\
\hline $10 \%$ & 25 & 17 & 21 & 14 & 14 & 16 & 14 & 22 & 17 \\
\hline $0 \%$ & 7 & 6 & 8 & 5 & 5 & 5 & 5 & 7 & 6 \\
\hline
\end{tabular}

Reference: Adapted from Pinto and Slevin (1998 apud RABECHINI, 2007, p. 54).
Factors that perform well are those with scores between $80 \%$ and 100\%. Factors situated between 50\% and $80 \%$ need attention and scores with lower than 50\% are considered critical (PINTO \& SLEVIN, 1998 apud RABECHINI, 2007).

Following the methodology of Slevin and Pinto (1987), the results allowed the identification of potential errors that the project may have, from the viewpoint of each stakeholder group, and from them, to propose recommendations. The identification of errors followed the Strategic and Tactical Effectiveness Matrix, set out in Chart 4.

Chart 4: Strategic and tactical effectiveness matrix of a project.

\begin{tabular}{|c|c|c|c|c|}
\hline \multirow{6}{*}{ 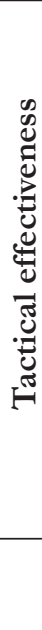 } & \multirow[t]{2}{*}{ High } & \multicolumn{2}{|c|}{$\begin{array}{c}\text { Potential for } \\
\text { mistakes types II } \\
\text { and III } \\
\text { High acceptance and }\end{array}$} & $\begin{array}{l}\text { High potential for } \\
\text { implementation } \\
\text { with success of the } \\
\text { project. }\end{array}$ \\
\hline & & misuse. & 2 & 1 \\
\hline & & & 3 & 4 \\
\hline & Low & \multicolumn{2}{|c|}{$\begin{array}{l}\text { High potential } \\
\text { for failure in } \\
\text { implementing the } \\
\text { project. }\end{array}$} & $\begin{array}{c}\text { Potential for } \\
\text { occurrence of errors } \\
\text { types I and IV. } \\
\text { Low acceptance and } \\
\text { low use. }\end{array}$ \\
\hline & & \multicolumn{2}{|l|}{ Low } & High \\
\hline & & \multicolumn{3}{|c|}{ Strategic effectiveness } \\
\hline
\end{tabular}

Reference: Slevin and Pinto (1987, p. 37).

According to the matrix, there are 4 (four) types of combinations arising from the performance of managers in balancing between strategy and tactics during the process. The type I error occurs when there is an inadequate level of tactical activities developed and few actions in favor of the project are implemented. The type II error occurs when an action that should not have been applied is adopted. The Type III error appears when you solve the wrong problem by effective action. Finally, the type IV error is when there is aware of the actions that should be perpetuated but, for a reason, are not.

The main limitation of this study is that the respondents expressed their personal perceptions on the subject, without necessarily representing the official position of the institutions to which they belong. Another limitation is the low participation of G1 members.

\section{RESULTS AND DISCUSSION}

Table 1 presents the results of mode and success percentage by critical factor by group studied. 
Table 1 - Mode and success rate per group.

\begin{tabular}{|c|c|c|c|c|c|c|c|c|c|c|c|c|c|c|c|c|}
\hline \multirow{3}{*}{$\begin{array}{l}\text { Critical } \\
\text { Factors }\end{array}$} & \multicolumn{4}{|c|}{ G1 $(n=1)$} & \multicolumn{4}{|c|}{$\mathrm{G} 2(\mathrm{n}=6)$} & \multicolumn{4}{|c|}{ G3 $(n=13)$} & \multicolumn{4}{|c|}{ G4 $(n=14)$} \\
\hline & Mode & $\%$ & Minimum & $\%$ & Mode & $\%$ & Minimum & $\%$ & Mode & $\%$ & Minimum & $\%$ & Mode & $\%$ & Minimum & $\%$ \\
\hline & & Success & & Success & & Success & & Success & & Success & & Success & & Success & & Success \\
\hline FCE 1 & 29 & $40 \%$ & 29 & $40 \%$ & 33 & $80 \%$ & 27 & $25 \%$ & 31 & $60 \%$ & 21 & $8 \%$ & 32 & $70 \%$ & 14 & $4 \%$ \\
\hline FCE 2 & 35 & $100 \%$ & 35 & $100 \%$ & 30 & $70 \%$ & 22 & $25 \%$ & & & & & & & & \\
\hline FCT 3 & 35 & $100 \%$ & 35 & $100 \%$ & 33 & $85 \%$ & 25 & $25 \%$ & 33 & $85 \%$ & 19 & $9 \%$ & 34 & $90 \%$ & 17 & $8 \%$ \\
\hline FCT 4 & 30 & $80 \%$ & 30 & $80 \%$ & 29 & $75 \%$ & 24 & $50 \%$ & & & & & & & & \\
\hline FCT 5 & 33 & $95 \%$ & 33 & $95 \%$ & 30 & $80 \%$ & 25 & $54 \%$ & & & & & & & & \\
\hline FCE 6 & 26 & $60 \%$ & 26 & $60 \%$ & 27 & $60 \%$ & 22 & $40 \%$ & & & & & & & & \\
\hline FСТ 7 & 33 & $95 \%$ & 33 & $95 \%$ & 33 & $94 \%$ & 23 & $45 \%$ & 30 & $80 \%$ & 14 & $10 \%$ & 23 & $45 \%$ & 13 & $9 \%$ \\
\hline FCT 8 & 32 & $70 \%$ & 32 & $70 \%$ & 32 & $70 \%$ & 13 & $5 \%$ & 25 & $20 \%$ & 5 & $0 \%$ & 13 & $5 \%$ & 7 & $0 \%$ \\
\hline FCE 9 & 35 & $100 \%$ & 35 & $100 \%$ & 35 & $100 \%$ & 35 & $100 \%$ & 35 & $100 \%$ & 16 & $9 \%$ & 35 & $100 \%$ & 20 & $20 \%$ \\
\hline
\end{tabular}

Caption: FCE - Critical Strategic Factor; FCT - Critical Tactical Factor.

\section{Reference: The author.}

The data show that the stakeholder groups studied were heterogeneous. G1 analysis was hampered because only 1 (one), among 6 (six) stakeholders of the group sent a response. Although quite receptive to the project, G2 considered FCE 1 (Objectives) below 50\% and FCE 6 (Planning) and FCT 8 (Customers) between $50 \%$ and $80 \%$. To G2, all other FCE and FCT perform well (above 80\%).

G2 is the only group where the percentage of the modes of all critical factors are above $50 \%$. Factors FCE 2 (Senior Management), FCT 4 (Personnel), FCE 6 (Planning) and FCT 8 (Customers) are rated between 50\% and $80 \%$, requiring greater attention by project managers.

G3 features factors FCT 3 (Organizational Strategy), FCT 7 (Infrastructure) and FCT 9 (Project Support) above $80 \%$. However, FCE 1 (Objectives), with 60\%, needs greater attention, whereas FCT 8 (Clients), with $20 \%$, is rated as critical.

G4 shows similar results to G3. The FCT 3 and FCE 9 factors are above $80 \%$, while FCE 1 (Objectives), with $70 \%$, needs greater attention and FCT 7 (Infrastructure), with 45\%, and FCT 8 (customers), with only $5 \%$ present critical results.

Only 2 (two) critical factors have good opinions among the 4 (four) groups: FCT 3 (Organizational Structure) and FCE 9 (Project Support). the factors that have the greatest differences in opinion are FCE 1 (Objectives), FCT 7 (Infrastructure), which shows great heterogeneity between groups.

G1, although relying on only the opinion of 1 (one) stakeholder, shows evidence of not having clearly understood the objectives of CDAer (FCE 1). This requires immediate intervention by managers, as representatives of this group have high power and their decisions affect the project fundamentally.
Representatives of the G4 fear that the aspects related to maintenance and infrastructure (FCT 7) are not adequately monitored. This perception of G4 faced with the opinions of stakeholders of G1, G2 and G3, which indicate, respectively, $95 \%, 94 \%$ and $80 \%$ success rate. The discrepancy of opinions can be explained by inadequate communication of managers with athletes and users of sports fields (G4 representatives) and points out an imbalance in monitoring among stakeholder groups.

This assertion is supported when analyzing the results of FCT 8 (Customers), a factor that had the worst performance in G2, G3 and G4, with the last two groups demonstrating to be seriously uninformed $(20 \%$ and $5 \%$ ). These numbers are indicative that their members feel excluded from the CDAer construction process. The managers own group (G2) shows only a 70\% success for FCT 8, were expected when at least $80 \%$. Though the project is moving the conception stage to planning within its life cycle (SLEVIN; PINTO, 1987), the data demonstrate there are deficiencies in tactical terms, which need to be corrected.

The difference between the values of modes and minimums for each critical factor is the most likely scenario of success that the project implementation will find. This understanding follows that mode is the value of greater agreement between all stakeholders within each group, while the minimum value is the greater dissatisfaction possible, i.e., the worst case scenario. The more we approach the minimum values and modes to $80 \%$, the greater the homogeneity among the stakeholders and therefore less likely is a conflict of interest to occur.

The comparison between the results of mode and minimum values for each critical factor evaluated by stakeholders is presented in Figures 2, 3, 4 and 5. 
G1, for having only 1 (one) assessor, has the same values for mode and minimum, compromising the analysis of heterogeneity within this group. Even so, this figure clearly shows the imbalance in the management of FCE 1 (Objectives) and FCE 6 (Planning) compared to the other factors.

Figure 2 - Comparison of the critical success factors appointed by G1, regarding the results of the modes and minimum values.

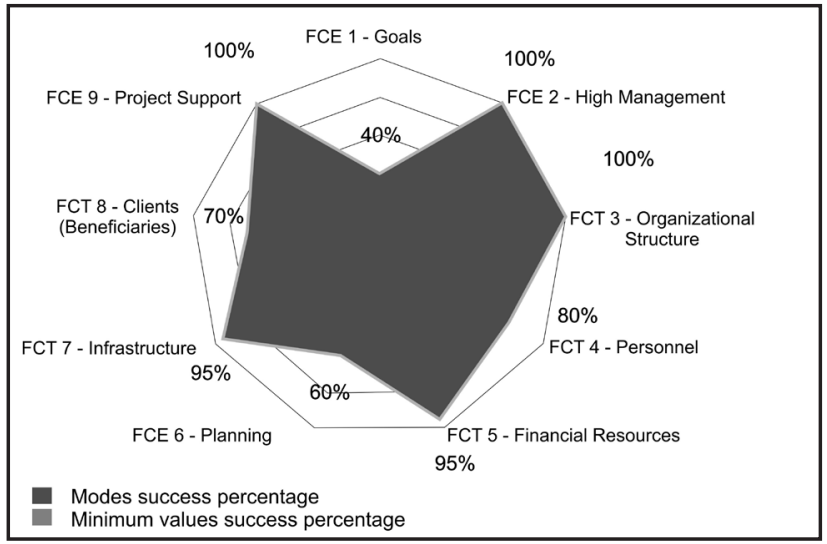

Reference: The author.

In observation to Figure 3, it is clear that FCT 8 (Customers) is the most heterogeneous critical factor for G2, with a difference of $65 \%$. Other factors such as FCE 1 (Objectives), FCE 2 (Senior Management) and FCT 3 (Organizational Structure), must also receive greater attention, since the difference between the values of modes and minimum is higher than $45 \%$, i.e., very heterogeneous.

Figure 3 - Comparison of the critical success factors appointed by $\mathrm{G} 2$, regarding the results of the modes and minimum values.

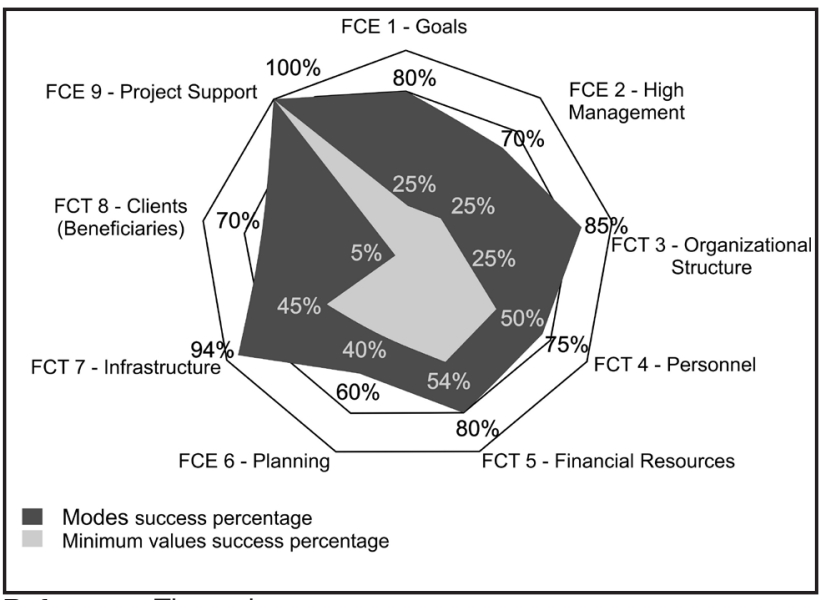

Reference: The author.

In the data observed in Figures 4 and 5, referring respectively to the $G 3$ and $G 4$, the scenario is even worse. The heterogeneity of the responses points out to big differences in all critical factors studied, mostly above $50 \%$. The worst case, again, is FCT 8 (Customers), where both mode as the minimum value are very low, and everyone involved agrees with that.
Figure 4 - Comparison of the critical success factors appointed by G3, regarding the results of the modes and minimum values.

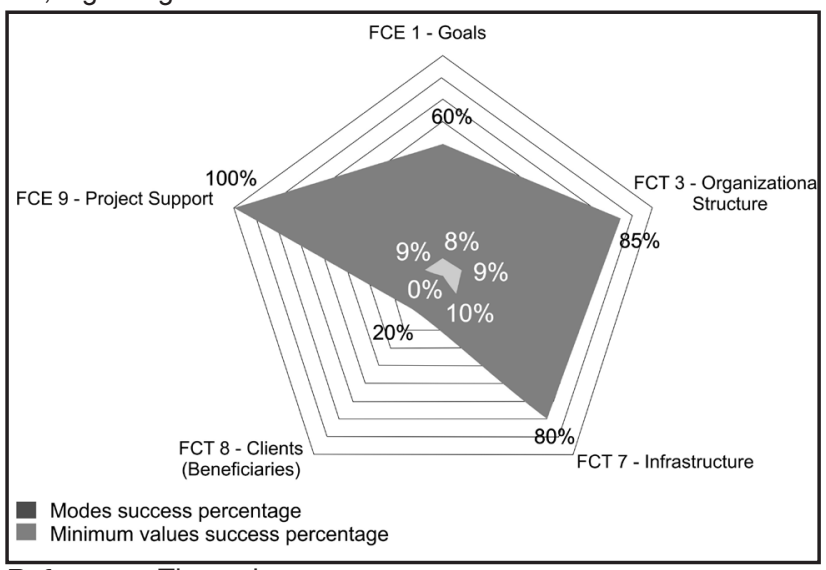

Reference: The author.

Figure 5 - Comparison of the critical success factors appointed by G4, regarding the results of the modes and minimum values.

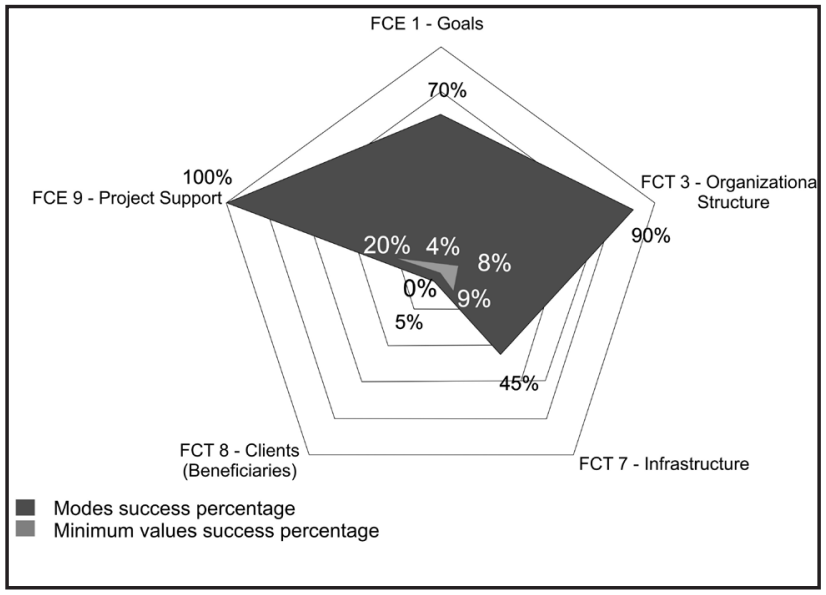

Reference: The author.

The analysis of this scenario suggests that there are clearly dissatisfied stakeholders in G3 and G4. According to Qualman's matrix (1997) shown in Chart 1 , these actors represent the class of those which have great interest, but little power. Their opinion is not enough to unable the project, but it's still important to keep partners, as they present ideas and help with small actions. This interpretation is confirmed by the analysis of the results of the FCE 9 (Support Project), which has minimum values at around $9 \%$ and $20 \%$ respectively for the G3 and G4. This implies that there are interested not in line with the creation of CDAer, probably because their interests are not being protected or because the communication of the project is not being carried out properly.

In this sense, it grows in importance the Strategic and Tactical Effectiveness Matrix presented in Chart 5, as the intersection of data on responses of each group indicate aspects being more or less effective and help identify potential management errors. 
Chart 5 - Effectiveness matrix between the strategic and tactical aspects.

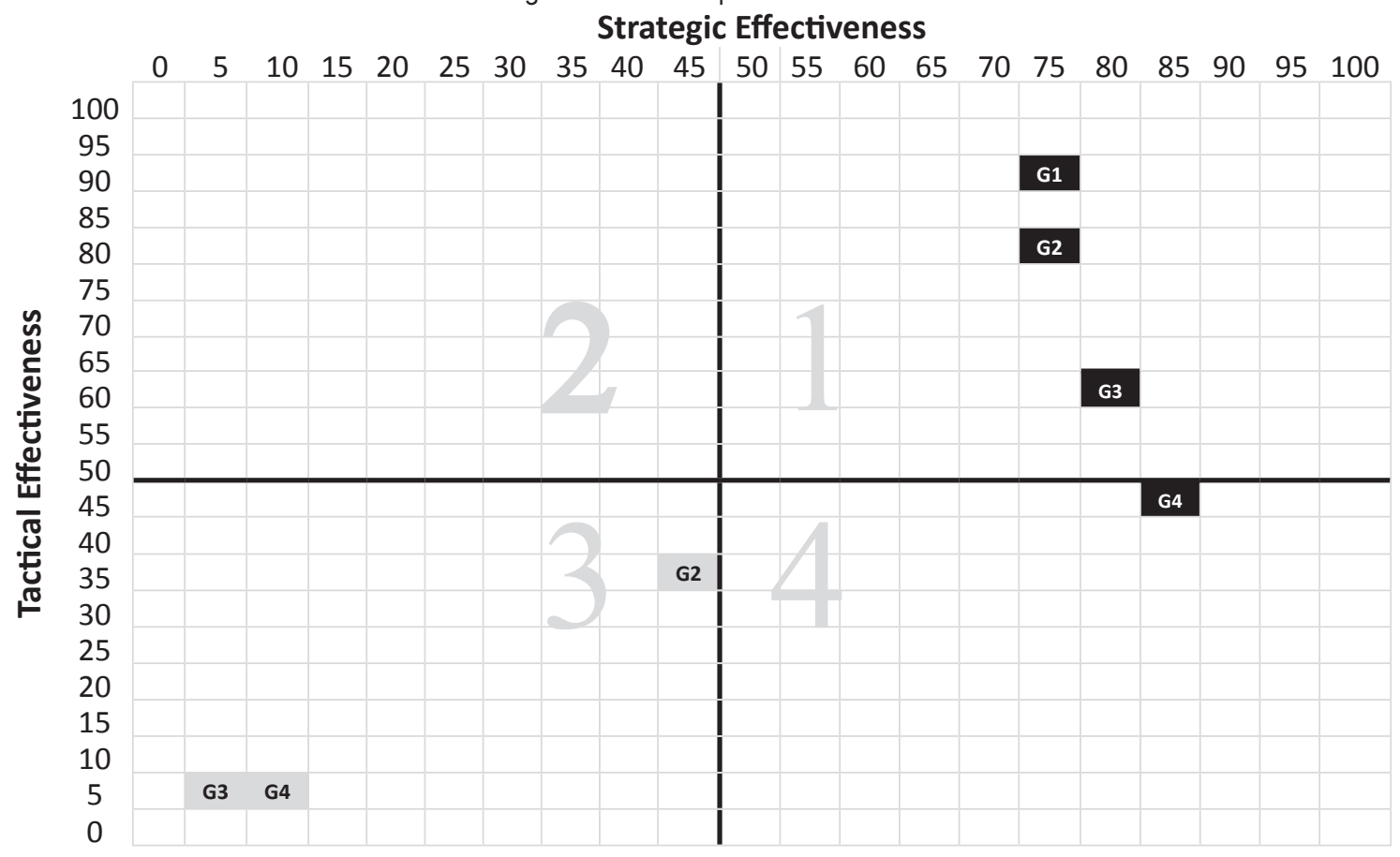

Caption:

$\square$ Interpolation based on minimum values.

- Interpolation based on the results of modes.

Obs.: for G1, mode and the minimum values are the same.

Reference: The author.

By analyzing the intersection of data related to mode, we see clearly that, in addition, the critical strategic factors (FCS) are inserted in the same range success rate between $75 \%$ and $85 \%$ (10\% confidence interval). However, it no longer occurs with critical tactical factor (FCT), whose range is much larger, ranging from $45 \%$ to $95 \%$ (50\% range).

Another immediate perception concerns the quadrant in which each group of stakeholders is. G1, G2 and G3 are in quadrant 1 which, according to Slevin and Pinto (1997), have great potential for successful implementation. But G4 is in quadrant 4, a high likely area of occurrence of Type I errors (project with low acceptance and low tactic efficiency) and type IV (low initiative for course correction, even knowing the flaws).

In the study of data intersection relating to the minimum values, it is observed that the project runs great risk of not being successfully implemented because the answers of 3 (three) groups are present in quadrant 3. In this case, as point out Slevin and Pinto (1987), in addition to the errors of type I and type IV, attention should be paid also to the type II (take action that should not have been adopted) and type III (collateral impact of corrective action, used to solve a particular problem, but it affects another).

These findings are important and, although apparently with a negative bias, the case is not lost. Rabechini (2007), adopting the same methodology, cites

a study in a Brazilian agribusiness company, in which the results were quite similar. The critical factor Senior Management was the one who received the highest scores, while the Customers and Communications factors needed more attention and received recommendations culminating in a managerial redirection of the project. In such cases, the author states that there are feasible possibilities for intervention by the project managers.

\section{CONCLUSION}

This study aimed at examining how the critical success factors, in the view of stakeholders, impact on the effectiveness of the CDAer implementation project.

The methodology led to investigate the critical success factors for most of the stakeholders of the G1, G2 and G3 are given the expected project and it presents a strategic effectiveness greater than tactics. The study also showed the presence of important actors (G4) not satisfied, because the project lacks a proper communications strategy and engagement of these actors in the process. The analysis of the minimum values also showed the types of potential errors of the project, presenting the problem of heterogeneity of opinions of stakeholders, as well.

Some conclusions are possible to be derived from this study. The first is the understanding that a distant management of key stakeholders creates uncertainty 
and leads to a reduction in support for the conduct of activities required. The second implies that awareness and support from key stakeholders should be a major factor in the structuring of the CDAer creation proposal, since its inception. Finally, the third infers that the project must have a clear diagnosis of its problems, especially those related to customers, personnel, financial resources and the organizational structure, respecting the strategictactical balancing the proposal from the beginning.

Given these conclusions, there are some recommendations that can be adopted to correct the project course. It stands out, among them, the need to develop a communication plan with a view to improving the exchange of information between managers and different stakeholder groups.

Another suggestion is that a support process must be prepared and defined to customers and beneficiaries of
CDAer, seeking to involve them in the design and tweaking up the scope of the implementation plan prepared. It is also associated the need to identify the reasons why some stakeholders not support the creation of CDAer and thus be drawn up one contingency plan to ensure an appropriate redirection of actions to be implemented.

As a further recommendation, it is proposed to increase the tactical effectiveness of the project by mapping and detailing the functions of the staff and resources to be employed in CDAer. Finally, although the analysis of the G1 data has been performed on the responses of only 1 (one) assessor, we must consider that this group is the most powerful stakeholders, as they are responsible for the final decisions related to the project. Thus, the approach and the search for orientation of these actors must be a constant throughout the process.

\section{REFERENCES}

BRASIL. Comando da Aeronáutica. Comissão de Desportos da Aeronáutica. Proposta de criação do Centro de Desportos da Aeronáutica (CDAer). Ofício no 10/VP/614, de 17/03/2015. Rio de Janeiro, 2015.

\section{FREEMAN, R.E. Strategic management: A} stakeholder approach. Boston: Pitman, 1984.

GOLDSCHIMIDT, A. Stakeholders: como interagir com tantos públicos diferentes. Revista RETS, 2005. Disponível em: <https://www.google.com.br/url?sa=t\&rct=j $\& q=\& e s r c=s \&$ source $=$ web\& $c d=2 \&$ ved $=0$ CCUQFjAB\&url= http\%3A\%2F\%2Fwww.novosolhos.com.br\%2Fdownload. php\%3Fextensa0\%3Drtf\%26original\%3DStakeholde rs\%2520-\%2520\%2520Partes\%2520Interessadas\% 2520RETS\%2520ago2005.rtf\%26servidor\%3Darq material\%2F59_58.rtf\&ei=H0zYU4SQLIfhsATOioKwDA\& usg=AFQjCNE9o1K7sZzEWXbTQ36v0KJ8pdcLaA\&sig2 =Y-o7eMV85hacis6tXENabg>. Acesso em: 26 jul. 2014.

MARCONI, M. A; LAKATOS, E. M. Fundamentação da metodologia científica. 5.ed. São Paulo: Atlas, 2003. 311p.

MOTTA, J. R. G. O negócio das arenas: profissionalismo esportivo, cultura e entretenimento. Future Studies Researsh Journal. São Paulo, v. 4, n. 2, p. 21-48, jul./dez. 2012.

PINTO, J. K.; SLEVIN, D.P. Critical success factors in effective project implementation. Sloan Management Review, 1987. Disponível em: <http://gspa.grade. nida.ac.th/pdf/PA\%20780\%20(Pakorn)/8.Critical\%20 Success\%20Factors\%20in\%20Effective\%20 Project\%20Implementati.pdf>. Acesso em: 24 jul. 2014.
QUALMAN, A. Note on stakeholder analysis. NGO Connect, 1997. Disponível em:<http://www. ngoconnect.net/documents/592341/749044/A+Note+ on+Stakeholder+Analysis>. Acesso em: 28 jul. 2014.

RABECHINI JR, R. O gerente de projetos na empresa. 2. ed. São Paulo: Atlas, 2007. 210p.

ROBINSON et al. Organising an Olympic Sport Organization. In: CAMY J.; ROBINSON, L. (Org). Managing Olympic Sports Organisations. Lausanne: Olympic Solidarity, p. 1-60, 2007.

ROCHA, C. M; BASTOS, F. C. Gestão do esporte: definindo a área. Rev. Bras. Educ. Fís. Esporte. São Paulo, v. 25, p. 91-103, dez. 2011.

SANTOS, F. R. O emprego da análise de stakeholders em um plano estratégico para a gestão da mobilidade sustentável: estudo de caso do campus da Universidade de Brasília. 2008. 99 f. Dissertação (Mestrado em Transportes) - Departamento de Engenharia Civil e Ambiental, Universidade de Brasília, Brasília, 2008.

SLEVIN, D. P.; PINTO, J.K. Balancing strategy and tatics in project implementation. Sloan Management Review, v. 29, n. 6, p. 33-41, 1987.

TOLEDO, J. R. Campeonato do índice de confiança social: Forças Armadas continuam do G4 e partidos seguem firme na lanterna. Forças Terrestres. Rio de Janeiro, Ago. 2013. Disponível em:<http://www. forte.jor.br/2013/08/01/campeonato-do-indice-deconfianca-social-forcas-armadas-continuam-no-g4e-partidos-seguem-firmes-na-lanterna/>. Acesso em: 27 jul. 2014. 